\title{
Pengaruh Pemberian Buah Naga Terhadap Tekanan Darah Pada Penderita Hipertensi Di Desa Bedahlawak Tembelang Jombang
}

\author{
Kurniawati $^{1)}$, Anthoni Hariyanto ${ }^{2)}$ \\ Fakultas Ilmu Kesehatan UNIPDU Jombang. \\ kurniawati@fik.unipdu.ac.id
}

\begin{abstract}
Abstrak
Buah naga memiliki kandungan antioksidan yang sangat tinggi. Kandungan bermanfaat untuk mencegah radikal bebas dan melindungi tubuh dari berbagai macam serangan penyakit, seperti hipertensi. Tujuan penelitian ini adalah untuk mengetahui pengaruh pemberian buah naga terhadap tekanan darah pada penderita hipertensi di Desa Bedahlawak Tembelang Jombang. Desain penelitian yang digunakan quasy-eksperimental dengan rancangan pretest-posttest control group design. Variabel independent pemberian buah naga merah. dependent tekanan darah dengan populasi sebanyak 36 orang, teknik sampling yang digunakan : random sampling didapatkan sampel jumlah setiap kelompok sebanyak 13 orang, data diuji dengan t-test paried dan t-test independent dengan tingkat kemaknaan $\leq 0,05$. Hasil penelitian menunjukkan tekanan darah sebelum dilakukan pemberian jus buah naga merah sistole rata-rata 150,77 dan setelah rata-rata sistole 142,31 , ada pengaruh pemberian buah naga terhadap tekanan darah pada penderita hipertensi di Desa Bedahlawak Tembelang Jombang yang signifikan dikarenakan nilai $t_{\text {hitung }}$ sebesar 3,091 dengan $p=0,009 \leq$ $(0,05)$. Berdasarkan hasil penelitian maka dapat disimpulkan bahwa ada pengaruh pemberian buah naga terhadap tekanan darah pada penderita hipertensi di Desa Bedahlawak Tembelang Jombang yang signifikan, maka diharapkan bagi tenaga kesehatan melakukan langkah-langkah untuk melakukan penekanan terjadinya hipertensi. Pemberian penyuluhan lebih intensif, serta melakukan melakukan eksperimen untuk menurunkan tekanan darah seperti pemberian jus buah naga merah, sehingga masyarakat mengerti dan paham khusus penderita hipertensi bahwa mengkonsumsi buah naga merah bermanfaat menurunkan tekanan darah, maka dengan demikian tekanan darah dapat dicegah dan ditangani secara optimal.
\end{abstract}

Kata kunci : Jus buah naga merah, dan tekanan darah

\begin{abstract}
The dragon fruit has very high antioxidant content. The content is useful for preventing free radicals and protects the body from various diseases, such as hypertension. The purpose of this study was to determine influence grant of dragon fruit on blood pressure in patients with hypertension in village Bedahlawak Tembelang Jombang. The design study is quasi-experimental with pretest-posttest control group design. The independent variable Award red dragon fruit. dependent blood pressure in patients with hypertension with a population of 26 people, sampling techniques were used: random sampling obtained samples of each group number as many as 13 people, then the results paried t-test and independent t-test with a significance level of $\leq 0.05$. The results of the study blood pressure before giving red dragon fruit juices average systolic 150.77 and after the average systole 142.31, there is the effect of dragon fruit on blood pressure in patients with hypertension in the village Bedahlawak Tembelang Jombang significant because the value $t_{\text {count }} 3.091, p=0.009<(0.05)$. Based on the results of the study it can be concluded that there is the effect of dragon fruit on blood pressure in patients with hypertension in the village Bedahlawak Tembelang Jombang significant, it is desirable for health workers to take steps to pressure the occurrence of hypertension, namely by providing counseling more intensive, and do conducting experiments to lower blood pressure such as the provision of a red dragon fruit juice, so the increase in blood pressure can be prevented and handled optimally.
\end{abstract}

Keywords: red dragon fruit juice, and blood pressure 


\section{PENDAHULUAN}

Hipertensi merupakan tantangan besar di Indonesia. Betapa tidak, hipertensi berkaitan kondisi yang sering ditemukan pada pelayanan kesehatan primer kesehatan. Hipertensi merupakan masalah kesehatan dengan prevalensi yang tinggi, yaitu sebesar 25,8\%, (Riskesdas,2013). Hipertensi diklasifikasikan berdasarkan penyebab (Hipertensi Primer/ Hipertensi Esensial, Hipertensi Sekunder/ Hipertensi Non Esensial), bentuk hipertensi (Hipertensi Pulmonal, Hipertensi Pada Kehamilan). Menurut Kementerian RI (2014), pengontrolan penderita hipertensi belum adekuat meskipun obat-obatan yang efektif banyak tersedia, sedangkan mengacu pada penderita hipertensi, menurut American heart Association (AHA) yang dikutip oleh Departemen Kementerian Kesehatan RI pada tahun 2014, bahwa penduduk Amerika yang menderita hipertensi mencapai 74,5 juta jiwa, namun hampir sekitar 90-95\% kasus tidak diketahui penyebabnya. Gejala penyakit hipertensi bervariasi pada masing-masing individu dan hampir sama dengan gejala penyakit lain. Gejala penyakit hipertensi, meliputi sakit kepala/rasa berat ditengkuk, vertigo, jantung berdebar-debar, mudah lelah, penglihatan kabur, telinga berdenging (tinnitus), dan mimisan.

Berdasarkan data Organisasi Kesehatan Dunia (WHO) tahun 2011, pada 2025 diperkirakan 1 miliar penduduk dunia menderita hipertensi. Dua pertiga jumlah itu tinggal di negara berkembang, termasuk Indonesia. Hipertensi telah mengakibatkan kematian sekitar 8 juta orang setiap tahun, 1,5 juta kematian terjadi di Asia Tenggara yang 1/3 populasinya menderita hipertensi sehingga dapat menyebabkan peningkatan beban biaya kesehatan. Selain itu Hipertensi banyak terjadi pada umur 35-44 tahun (6,3\%), umur 45-54 tahun (11,9\%), umur 55-64 tahun (17, 2\%). Sedangkan menurut status ekonomi, proporsi Hipertensi terbanyak pada tingkat menengah bawah $(27,2 \%)$ dan menengah $(25,9 \%)$. (Kementerian Kesehatan RI, 2016). Sedangkan, Jumlah penderita hipertensi di Jawa Timur sejumlah 4,89\%. Pada tahun 2014 di Kabupaten Jombang pengukuran tekanan darah yang dilakukan pada penduduk usia $>15$ tahun ditargetkan sejumlah 930.573. Dari jumlah tersebut yang diperiksa tekanan darahnya adalah sejumlah 233.477 (25,09\%). Hasil dari pemeriksaan ini ditemukan penderita hipertensi sebesar 37.604 (16,11\%) (Dinkes Jombang,
2014).

Hasil studi pendahuluan yang dilakukan oleh peneliti pada bulan Novermber 2016 di Desa Bedahlawak Tembelang Jombang, didapatkan hasil sebagai berikut :

Tabel 1. Data Tekanan Darah di Desa Bedahlawak Tembelang Jombang

\begin{tabular}{|c|c|c|c|c|c|c|}
\hline \multirow[b]{2}{*}{$\begin{array}{l}\text { Jenis } \\
\text { Kelamin }\end{array}$} & \multirow[b]{2}{*}{ Jml } & \multicolumn{2}{|c|}{$\begin{array}{c}\text { Usia } \\
\text { (tahun) }\end{array}$} & \multicolumn{3}{|c|}{$\begin{array}{c}\text { Jenis Tekanan Darah } \\
(\mathrm{mmHg})\end{array}$} \\
\hline & & $\begin{array}{l}45- \\
59\end{array}$ & $\begin{array}{l}60- \\
70\end{array}$ & $\begin{array}{l}\text { Norm } \\
\text { al } \\
\leq 140 / 90)\end{array}$ & $\begin{array}{l}\text { Hiperte } \\
\text { nsi } \\
(>140 / 90 \\
\text { / } \\
<160 / 90)\end{array}$ & $\begin{array}{l}\text { Hipert } \\
\text { ensi } \\
\text { berat } \\
\text { (> } \\
160 / 90 \\
\text { ) }\end{array}$ \\
\hline & 2 & 3 & - & 3 & - & - \\
\hline Laki-laki & 0 & - & 17 & - & 15 & 2 \\
\hline Perempu & 1 & 7 & - & 7 & - & - \\
\hline an & 6 & - & 9 & - & 9 & - \\
\hline Jumlah & 3 & 1 & 26 & 10 & 24 & 2 \\
\hline
\end{tabular}

Berdasarkan tekanan darah tersebut memerlukan suatu perawat yang tepat yaitu selain gizi seimbang, tidak merokok, istirahat yang cukup dan berolahraga. Hipertensi atau yang lebih dikenal dengan penyakit darah tinggi adalah peningkatan abnormal tekanan darah, baik tekanan darah sistolik maupun tekanan darah diastolik. Dalam keadaan normal, tekanan darah sistolik (saat jantung memompakan darah) kurang dari $120 \mathrm{mmHg}$ dan tekanan darah diastolik (saat jantung istirahat) kurang dari $80 \mathrm{mmHg}$ (Fridalni, 2013). Menurut Beevers, D. G, (2000) dalam Dwipayanti (2011), faktor yang berpengaruh memicu terjadinya hipertensi diantaranya adalah faktor genetik, jenis kelamin, umur, obesitas, dan konsumsi garam serta alkohol. Tekanan darah yang meningkat bisa berpengaruh pada pembuluh darah jantung. Bila berlangsung lama akan terjadi gagal jantung yang disusul dengan sesak nafas, akibat yang lebih serius lagi adalah terjadinya stroke dan kematian karena aliran darah tidak lancar, sehingga suplai oksigen yang dibawa oleh sel-sel darah merah menjadi terlambat.

Penderita hipertensi dengan tekanan darah yang tinggi akan menjalani hidup dengan bergantung pada obat-obatan dan kunjungan teratur ke dokter untuk mendapatkan resep ulang dan check-up. Data WHO melaporkan dari 50\% penderita hipertensi yang 
diketahui hanya $25 \%$ yang mendapat pengobatan, dan hanya 12,5\% yang diobati dengan baik (adequately treated cases) karena mahalnya biaya yang diperlukan selama proses terapi. Selain itu, penggunaan obat-obatan hipertensi sering menimbulkan efek samping yang tidak diinginkan yang merupakan hal yang harus dihindari oleh penderita hipertensi. Salah satu contoh efek samping yang umum terjadi adalah meningkatnya kadar gula dan kolesterol, kelelahan serta kehilangan energi. Tidak sedikit penderita yang harus mengkonsumsi obat lain untuk menghilangkan efek samping dari pengobatan hipertensinya. Hal inilah yang membuat pasien tidak patuh terhadap terapi pengobatan dan beralih mencari terapi yang lain (Kharisna, 2012).

Terapi non farmakologis yakni modifikasi gaya hidup memiliki peran penting baik bagi individu non-hipertensi maupun individu yang telah hipertensi. Salah satu modifikasi gaya hidup ialah dengan pengaturan pola makan atau diet. Buah dan sayur merupakan komponen penting dari diet yang sehat (Lizel, 2013). Beberapa buahbuahan seperti buah naga menawarkan manfaat kesehatan yang besar. Menurut penelitian Yanti (2015), buah naga memiliki kandungan gizi yang tinggi dan baik bagi kesehatan diantaranya vitamin $\mathrm{C}, \mathrm{B} 1, \mathrm{~B} 3$, B12, betakaroten, fosfor, kalsium, gula sederhana, protein, serat dan lycopine. Beberapa manfaat konsumsi buah naga terhadap kesehatan adalah sebagai antioksidan yaitu mencegah serangan radikal bebas yang dapat menyebabkan penyakit kanker dan masalah kesehatan lainnya, megontrol gula darah terutama bagi penderita diabetes tipe 2 , menurunkan tekanan darah, menetralkan racun, menjaga kesehatan mata, melancarkan pencernaan dan menurunkan berat badan. Pada penelitian Amelia (2015), buah naga merah merupakan buah dari suku Cactaceae, yang mulai banyak dikonsumsi di Indonesia. Buah naga merah secara berkala dapat mencegah dan mengobati osteoporosis, hipertensi, diabetes dan menurunkan kolesterol.

Berdasarkan latar belakang di atas maka peneliti ingin membuktikan apakah buah naga mampu menurunkan tekanan darah pada penderita hipertensi, maka peneliti tertarik melakukan penelitian dengan judul "Pengaruh Pemberian Buah Naga Terhadap Tekanan
Darah Pada Penderita Hipertensi di Desa Bedahlawak Tembelang Jombang".

\section{BAHAN DAN METODE PENELITIAN}

Penelitian ini quasy-eksperimental dengan rancangan pretest-posttest control group design. Dalam rancangan ini dilakukan radominsasi, artinya pengelompokkan anggota-anggota kelompok kontrol dan kelompok eksperimen dilakukan berdasarkan acak atau random. Populasi penelitian semua penderita hipertensi di Desa Bedahlawak Tembelang Jombang sebanyak 36 orang yang memenuhi kriteria inklusi dan eksklusi.

Pengumpulan data dilakukan dengan observasi. Pengamatan berdasarkan pengukuran alat ukur yang digunakan pada penelitian ini adalah sfigmomanometer air raksa dan stetoskop, yaitu alat mekanik untuk mengukur tekanan darah yang telah dikalibrasikan terlebih dahulu. Tekanan darah responden pada kelompok eksperimen diukur sebelum dan sesudah diberikan edukasi dan jus buah naga merah, sedangkan tekanan darah responden pada kelompok kontrol diukur pemberian edukasi kemudian hasilnya dicatat pada lembar hasil pengukuran.

Analisis data dan uji statistik yang akan dilakukan dalam penelitian ini meliputi : Analisis univariate : karakteristik sampel data kontinue didiskripsikan dalam parameter $\mathrm{n}$, mean, SD minimum maksimum. Karakteristik sampel data didiskripsikan dalam $\mathrm{n}$ dan $\%$.

Analisis bevariate digunakan untuk mengetahui pengaruh pemberian buah naga terhadap tekanan darah pada penderita hipertensi dilakukan hipotesis melalui uji $t$-test paired dikarenakan sampelnya berpasangan, kemudian dilanjutkan uji statistik t-test independent. dengan tingkat kemaknaan $\mathrm{p}<0,05$.

\section{HASIL PENELITIAN}

\section{Data Umum}

Dengan hasil penelitian tentang pengaruh pemberian buah naga terhadap tekanan darah pada penderita hipertensi di Desa Bedahlawak Tembelang Jombang, sebagian berikut :

Tabel 1. Distribusi Frekuensi Responden Berdasarkan Karakteristik Umum Responden

Pada kelompok Perlakuan dan Kontrol

di Desa Bedahlawak Tembelang Jombang 


\begin{tabular}{|c|c|c|c|c|c|}
\hline \multirow[t]{2}{*}{ No. } & \multirow[t]{2}{*}{ Karakteristik } & \multicolumn{2}{|c|}{$\begin{array}{l}\text { Kelompok } \\
\text { Perlakuan }\end{array}$} & \multicolumn{2}{|c|}{$\begin{array}{c}\text { Kelompok } \\
\text { Kontrol }\end{array}$} \\
\hline & & $\mathbf{N}$ & $\%$ & $\mathbf{F}$ & $\%$ \\
\hline \multirow[t]{3}{*}{1.} & Jenis kelamin & & & & \\
\hline & a. Laki-laki & 2 & 15,4 & 1 & 7,7 \\
\hline & b. Perempuan & 11 & 84,6 & 12 & 92,3 \\
\hline \multirow[t]{4}{*}{2.} & Umur & & & & \\
\hline & a. 45-59 tahun & 3 & 23,1 & 3 & 23,1 \\
\hline & b. 60-70 tahun & 10 & 76,9 & 10 & 76,9 \\
\hline & c. $>70$ tahun & 0 & 0 & 0 & 0 \\
\hline \multirow[t]{5}{*}{3.} & Pendidikan & & & & \\
\hline & a. Tidak sekolah & 0 & 0 & 1 & 7,7 \\
\hline & $\begin{array}{l}\text { b. Dasar (SD, } \\
\text { SMP) }\end{array}$ & 12 & 92,3 & 12 & 92,3 \\
\hline & $\begin{array}{ll}\text { c. } & \text { Menengah } \\
\text { (SMA, SMK) }\end{array}$ & 1 & 7,7 & 0 & 0 \\
\hline & $\begin{array}{ll} & \text { Tinggi } \\
\text { d. } & \text { (Perguruan } \\
\text { tinggi) }\end{array}$ & 0 & 0 & 0 & 0 \\
\hline
\end{tabular}

4. Berat badan

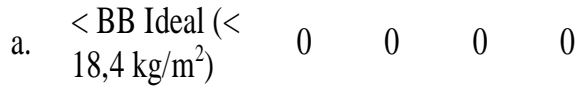
$<$ BB Ideal

b. $\quad(18,5-24,9 \quad 0 \quad 0 \quad 000$ $\left.\mathrm{kg} / \mathrm{m}^{2}\right)$

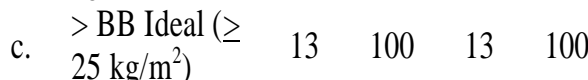

5. Merokok

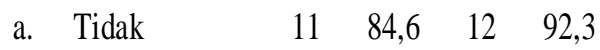

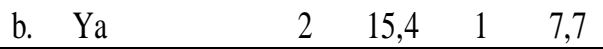

6. Konsumsi garam

$\begin{array}{lllll}\text { a. Tidak } & 0 & 0 & 0 & 0\end{array}$

$\begin{array}{llllll}\text { b. } & \text { Ya } & 13 & 100 & 13 & 100\end{array}$

7. Frekuensi garam

yang dikonsumsi

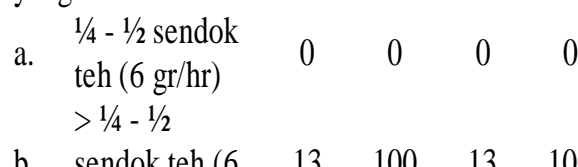

b. $\quad$ sendok teh $\left(\begin{array}{lllll}6 & 13 & 100 & 13 & 100\end{array}\right.$ $\mathrm{gr} / \mathrm{hr}$ )

8. Konsumsi kopi

$\begin{array}{llllll}\text { a. } & \text { Tidak } & 7 & 53,8 & 8 & 61,5\end{array}$

\begin{tabular}{lllll} 
b. $\mathrm{Ya}$ & 6 & 46,2 & 5 & 38,5 \\
\hline
\end{tabular}

9. Konsumsi alkohol

$\begin{array}{llllll}\text { a. } & \text { Tidak } & 13 & 100 & 0 & 0\end{array}$

$\begin{array}{lllll}\text { b. Ya } & 0 & 0 & 13 & 100\end{array}$

10. Aktivitas olahraga

$\begin{array}{llcccc}\text { a. } & \text { Tidak } & 13 & 100 & 0 & 0 \\ \text { b. } & \text { Ya } & 0 & 0 & 13 & 100\end{array}$

11. Konsumsi obat darah tinggi

\begin{tabular}{llllcl} 
a. & Tidak & 9 & 69,2 & 3 & 23,1 \\
b. & Ya & 4 & 30,8 & 10 & 76,9 \\
\hline
\end{tabular}

Sumber : Data Primer
Berdasarkan tabel 1 di atas menunjukkan bahwa pada kelompok perlakuan sebagian besar responden jenis kelamin laki-laki $(84,6 \%)$ dan sebagian kecil perempuan $(15,4 \%)$, sebagian besar responden berumur $60-70$ tahun $(76,9 \%)$ dan sebagian kecil berumur $45-59$ tahun $(23,1 \%)$, sebagian besar pendidikan terakhir Dasar (SD, SMP) (92,3\%) dan sebagian kecil menengah (SMA, SMK) (7,7\%), mayoritas berat badan > BB ideal $\left(\geq 25 \mathrm{~kg} / \mathrm{m}^{2}\right)(100 \%)$, sebagian besar responden tidak merokok $(84,6 \%)$ dan sedangkan sebagian kecil merokok $(15,4 \%)$, mayoritas responden mengkonsumsi garam (100\%), mayoritas responden frekuensi garam yang dikonsumsi $>1 / 4-1 / 2$ sendok teh $(6 \mathrm{gr} / \mathrm{hr})$ $(100 \%)$, lebih dari setengah responden mengkonsumsi kopi $(53,8 \%)$ dan hampir setengah responden tidak mengkonsumsi kopi $(46,2 \%)$, mayoritas responden tidak mengkonsumsi alkohol (100\%), mayoritas tidak aktivitas olahraga (100\%), sebagian besar responden konsumsi obat darah tinggi $(69,2 \%)$ dan sebagian kecil tidak mengkonsumsi obat darah tinggi $(30,8 \%)$.

Pada kelompok kontrol sebagian besar responden jenis kelamin perempuan $(92,3 \%)$ dan sebagian kecil laki-laki $(7,7 \%)$, sebagian besar responden berumur 60-70 tahun (76,9\%) dan sebagian kecil berumur 45-59 tahun $(23,1 \%)$, sebagian besar pendidikan terakhir Dasar (SD, SMP) $(92,3 \%)$ dan sebagian kecil tidak sekolah $(7,7 \%)$, mayoritas berat badan > BB ideal $\left(\geq 25 \mathrm{~kg} / \mathrm{m}^{2}\right)(100 \%)$, sebagian besar responden tidak merokok $(92,3 \%)$ dan sedangkan sebagian kecil merokok (7,7\%), mayoritas responden mengkonsumsi garam (100\%), mayoritas responden frekuensi garam yang dikonsumsi $>1 / 4-1 / 2$ sendok teh $(6 \mathrm{gr} / \mathrm{hr})$ (100\%), sebagian besar responden mengkonsumsi kopi $(61,5 \%)$ dan hampir setengah responden tidak mengkonsumsi kopi $(38,5 \%)$, mayoritas responden tidak mengkonsumsi alkohol (100\%), mayoritas tidak aktivitas olahraga (100\%), sebagian besar responden konsumsi obat darah tinggi $(76,9 \%)$ dan sebagian kecil tidak mengkonsumsi obat darah tinggi $(23,1 \%)$.

\section{Data Khusus}

1. Tekanan Darah Sebelum Perlakuan dan Kontrol Pada Penderita Hipertensi di Desa Bedahlawak Tembelang Jombang 
Tabel 2. Distribusi Frekuensi Responden

Berdasarkan Tekanan Darah Sebelum

Perlakuan Pada Penderita Hipertensi di Desa

Bedahlawak Tembelang Jombang

\begin{tabular}{|c|c|c|c|}
\hline \multirow[t]{2}{*}{ No } & \multirow[t]{2}{*}{ Tekanan Darah } & $\begin{array}{l}\text { Kelompok } \\
\text { Perlakuan }\end{array}$ & $\begin{array}{c}\text { Kelompok } \\
\text { Kontrol } \\
\end{array}$ \\
\hline & & & $\mathbf{F}$ \\
\hline
\end{tabular}

\begin{tabular}{llcccc}
\hline 1. & Prehipertensi & 4 & 30,77 & 1 & 7,7 \\
\hline 2. & Hipertensi derajat I & 3 & 23,08 & 8 & 61,5 \\
\hline 3. & Hipertensi derajat II & 6 & 46,15 & 4 & 30,8
\end{tabular}

3. Hipertensi derajat II

Sumber : Data Primer

Dari tabel 2 di atas menunjukkan bahwa tekanan darah sebelum perlakuan pada kelompok eksperimen didapatkan hampir setengah responden kategori hipertensi derajat III $(46,15 \%)$, hipertensi derajat I $(23,08 \%)$ dan prehipertensi $(30,77 \%)$. Pada kelompok kontrol sebagian besar responden tekanan darah kategori hipertensi derajat I $(61,5 \%)$ sedangkan sebagian kecil responden kategori prehipertensi $(7,7 \%)$.

2. Tekanan Darah Sesudah Perlakuan Pada Penderita Hipertensi di Desa Bedahlawak Tembelang Jombang

Tabel 3 Distribusi Frekuensi Responden Berdasarkan Tekanan Darah Sesudah

Perlakuan dan Kontrol Pada Penderita Hipertensi

di Desa Bedahlawak Tembelang Jombang

\begin{tabular}{llcccc}
\hline \multirow{2}{*}{ No } & \multirow{2}{*}{ Tekanan Darah } & \multicolumn{2}{c}{$\begin{array}{c}\text { Kelompok } \\
\text { Perlakuan }\end{array}$} & \multicolumn{2}{c}{$\begin{array}{c}\text { Kelompok } \\
\text { Kontrol }\end{array}$} \\
\cline { 3 - 6 } & & F & \% & F & \% \\
\hline 1. & Prehipertensi & 5 & 38,46 & 0 & 0 \\
2. & Hipertensi derajat I & 3 & 23,08 & 6 & 46,2 \\
3. & Hipertensi derajat II & 5 & 38,46 & 7 & 53,8 \\
\hline
\end{tabular}

Sumber : Data Primer, 2017

Dari tabel 3 di atas menunjukkan bahwa tekanan darah sesudah perlakuan pada kelompok eksperimen didapatkan hampir setengah responden kategori prehipertensi $(38,46 \%)$, hipertensi derajat I $(23,08 \%)$ dan derajat II $(38,46 \%)$. Pada kelompok kontrol lebih setengah responden tekanan darah kategori hipertensi derajat II (53,8\%) sedangkan hampir setengah responden tekanan darah kategori hiperensi derajat I $(46,2 \%)$.

3. Pengaruh Pemberian Buah Naga Terhadap Tekanan Darah Pada Penderita
Hipertensi di Desa Bedahlawak

Tembelang Jombang.

Tabel 4 Pengaruh Pemberian Buah Naga

Terhadap Tekanan Darah Pada Penderita Hipertensi di Desa Bedahlawak Tembelang Jombang.

\begin{tabular}{|c|c|c|c|c|c|}
\hline \multirow{2}{*}{ - Kelompok } & \multicolumn{2}{|c|}{ Mean } & \multicolumn{2}{|c|}{ SD } & \multirow{2}{*}{$\begin{array}{c}\text { Beda mean } \\
(95 \% \mathrm{CI})\end{array}$} \\
\hline & Sebelum & Sesudah & Sebelum & Sesudah & \\
\hline Perlakuan & 150,77 & 142,31 & 21,78 & 23,15 & $(2,50-14.43) 0,009$ \\
\hline Kontrol & 142,31 & 142,31 & 16,41 & 15,61 & $(5.98-0.17) 0,040$ \\
\hline
\end{tabular}

Sumber : Data Primer

Dari tabel 4 di atas didapatkan selisih mean sebesar 8,46 ini menunjukkan bahwa pengaruh perlakuan sebesar $5,94 \%$, sedangkan dari uji statistik $t$-test paired didapatkan nilai $t_{\text {hitung }}$ sebesar 3,091 (sebelum dan sesudah perlakuan) dengan nilai probabilitas sebesar 0,009 lebih kecil dari nilai standart signifikan $(\alpha=0,05)$, maka $\mathrm{H}_{1}$ diterima yang artinya ada pengaruh pemberian buah naga terhadap tekanan darah pada penderita hipertensi di Desa Bedahlawak Tembelang Jombang yang signifikan.

Pada kelompok kontrol didapatkan selisih mean sebesar -3,08 ini menunjukkan bahwa pengaruh kontrol sebesar 2,01\%, akan tetapi arahnya negatif. Dari uji statistik $t$-test paired didapatkan nilai thitung sebesar $-2,309$ (sebelum dan sesudah kontrol) dengan nilai probabilitas sebesar 0,040 lebih kecil dari nilai standart signifikan $(\alpha=0,05)$, maka $\mathrm{H}_{1}$ diterima yang artinya ada pengaruh tindakan kelompok kontrol terhadap tekanan darah pada penderita hipertensi di Desa Bedahlawak Tembelang Jombang yang signifikan dengan arah pengaruh negatif.

Tabel 5 Perbedaan Antara Kelompok

Perlakuan dan Kontrol Terhadap Tekanan

Darah Pada Penderita Hipertensi di Desa

Bedahlawak Tembelang Jombang.

\begin{tabular}{|l|c|c|c|c|}
\hline Kelompok & Mean & SD & $\begin{array}{c}\text { Beda mean } \\
\text { (95\% CI) }\end{array}$ & p \\
\hline Perlakuan & 8,46 & 9,87096 & $(5,25450-$ & 0,001 \\
\hline Kontrol & $-3,08$ & 4,80384 & $17,82242)$ & \\
\hline
\end{tabular}

Sumber : Data Primer 2017

Berdasarkan tabel 5 di atas menunjukkan nilai probabilitas sebesar 0,001 lebih kecil dari nilai standart signifikan $(\alpha=$ 
0,05), maka $\mathrm{H}_{1}$ diterima yang artinya ada perbedaan antara kelompok perlakuan dengan kontrol terhadap tekanan darah pada penderita hipertensi di Desa Bedahlawak Tembelang Jombang yang signifikan.

\section{PEMBAHASAN}

Dengan hasil penelitian tentang pengaruh pemberian buah naga terhadap tekanan darah pada penderita hipertensi di Desa Bedahlawak Tembelang Jombang, sebagian berikut :

1. Tekanan darah sebelum perlakuan pada penderita hipertensi di Desa Bedahlawak Tembelang Jombang

Dari hasil penelitian pada tabel 2 menunjukkan bahwa tekanan darah sebelum perlakuan pada kelompok eksperimen didapatkan hampir setengah responden kategori hipertensi derajat III $(46,15 \%)$, hipertensi derajat I $(23,08 \%)$ dan prehipertensi $(30,77 \%)$. Pada kelompok kontrol sebagian besar responden tekanan darah kategori hipertensi derajat I (61,5\%) sedangkan sebagian kecil responden kategori prehipertensi $(7,7 \%)$.

Tekanan darah merupakan ukuran tekanan darah di dalam arteri yang didapat dari setiap denyut jantung. Biasanya seorang dokter atau perawat dapat mendengar tekanan darah dengan menempatkan stetoskop di arteri dan memompa sabuk yang dilingkarkan pada lengan (Adib, 2011). Hipertensi atau darah tinggi adalah suatu keadaan ketika seseorang mengalami peningkatan tekanan darah di atas normal (Akmal, dkk, 2010).

Dari uraian di atas bahwa hampir setengah responden pada kelompok eksperimen kategori hipertensi derajat II, dan pada kelompok kontrol sebagian besar responden tekanan darah kategori hipertensi II, hal ini dikarenakan responden di Desa Bedahlawak Tembelang Jombang sebagian besar berusia 60-70 tahun, yang mana usia tersebut memasuki usia lanjut secara alami proses penuaan yang tidak dapat dihindari yang dapat menyebabkan penurunan fungsi sel tubuh secara keseluruhan, hal inilah yang mempengaruhi gairah hidup kurang aktif, seperti malas berolahraga. Dengan kurangnya aktivitas dalam sehari-hari seperti olahraga dapat menyebab penurunan kualitas aktivitas jantung memompa darah yang mengakibatkan peningkatan tekanan darah, hal ini ditemukan di lapangan bahwa baik pada kelompok eksperimen maupun kelompok kontrol mayoritas tidak melakukan aktivitas olahraga.

2. Tekanan darah sesudah perlakuan pada penderita hipertensi di Desa Bedahlawak Tembelang Jombang

Dari hasil penelitian pada tabel 3 menunjukkan bahwa tekanan darah sesudah perlakuan pada kelompok eksperimen didapatkan hampir setengah responden kategori prehipertensi $(38,46 \%)$, hipertensi derajat I $(23,08 \%)$ dan derajat II $(38,46 \%)$. Pada kelompok kontrol lebih setengah responden tekanan darah kategori hipertensi derajat II $(53,8 \%)$ sedangkan hampir setengah responden tekanan darah kategori hiperensi derajat I $(46,2 \%)$.

Menurut penelitian Figueroa (2012) Fridalni (2013) mengatakan bahwa postasium, vitamin $\mathrm{C}$, karbohidrat, likopen yangberfungsi untuk meningkatkan kerja jantung serta silitrus yang mampu mendorong aliran darah ke seluruh bagian tubuh serta member efek arfosidiak dan vitamin B6 yang dapat merangsang hormone dalam otak untuk mengatasi kecemasan. Sedangkan pada penelitian Komang, dkk (2014) bahwa buah naga juga mengandung antioksidan yang bermanfaat dalam menjaga elastisitas pembuluh darah, mampu memperbaiki sistem perdarahan darah. Selain itu juga kandungan buah naga mempunyai kandungan senyawa vitamin B3, vitamin ini sendiri bermanfaat untuk anda yang mempunyai masalah kadar kolestrol tinggi, dengan mengkonsumsi jus atau buah naga secara langsung dapat menyembuhkan masalah tekanan darah tinggi (Solehudin, 2014).

Dari uraian di atas bahwa tekanan darah sesudah perlakuan pada kelompok eksperimen didapatkan hampir setengah responden kategori prehipertensi, hal ini dikarenakan pemberian jus buah naga merah, yang mana pemberian jus buah naga merah diberikan 1 gelas $( \pm 200 \mathrm{cc}) 3$ kali dalam 1 minggu selama 1 bulan mampu mempengaruhi tekanan darah yang sebelumnya setengah responden kategori hipertensi derajat II menurun dengan hampir setengah dari jumlah seluruh responden kategori prehipertensi. Kandungan buah naga merah memiliki kandungan antioksidan yang sangat tinggi sehingga mencegah radikal bebas dan melindungi tubuh dari berbagai macam serangan penyakit, seperti hipertensi. Pada kelompok kontrol hampir setengah responden 
kategori prehipertensi mengalami peningkatan, yaitu lebih setengah responden tekanan darah kategori hipertensi derajat II dan hampir setengah responden tekanan darah kategori hiperensi derajat I, hal ini dikarenakan responden kurang memperhatikan edukasi tentang kebiasaan sehari-hari yang dapat meningkatkan tekanan darah yang disampaikan oleh peneliti kurang diperhatikan, dimana responden masih melakukan kebiasaan seharihari yang dapat memicu tekanan darah seperti mengkonsumi garam yang berlebihan, kopi dan kurang beraktivitas olahraga.

3. Pengaruh pemberian buah naga terhadap tekanan darah pada penderita hipertensi di Desa Bedahlawak Tembelang Jombang.

Dari hasil penelitian tabel 4 didapatkan sistole rata-rata sebelum pemberian jus buah naga 150,77 dan setelah diberikan jus buah naga rata-rata sistole 142,31 , sedangkan selisih mean sebesar 8,46 ini menunjukkan bahwa pengaruh perlakuan sebesar 5,94\%, sedangkan dari uji statistik t-test paired didapatkan nilai thitung sebesar 3,091 (sebelum dan sesudah perlakuan) dengan nilai probabilitas sebesar 0,009 lebih kecil dari nilai standart signifikan $(\alpha=0,05)$, maka $\mathrm{H}_{1}$ diterima yang artinya ada pengaruh pemberian buah naga terhadap tekanan darah pada penderita hipertensi di Desa Bedahlawak Tembelang Jombang yang signifikan.

Menurut Simpatupang (2007) dalam Mega (2016), buah naga mengandung vitamin $\mathrm{C}$ yang tinggi, buah naga mengandung $80 \%$ air. Zat nutrisi lain yang terkandung di dalam buah naga ialah serat, kalsium, zat besi, fosfor yang cukup bermanfaat untuk mengatasi penyakit darah tinggi. Di dalam 100 gr buah naga, mengandung kalori $60 \mathrm{kkal}$, protein 0 , 53 gr, karbohidrat 11,5 gr, serat 0,71 gr, kalsium 134,5 mg, fosfor $87 \mathrm{mg}$, zat besi 0,65 $\mathrm{mg}$, vitamin C 9,4 mg, serta kandungan airnya sebanyak 90\% (Harjana, 2013). Menurut Solomon (2016), buah naga memiliki kandungan antioksidan yang sangat tinggi. Kandungan ini bermanfaat untuk mencegah radikal bebas dan melindungi tubuh dari berbagai macam serangan penyakit, seperti kanker dan gangguan kesehatan lainnya, termasuk hipertensi.

Dari hasil tekanan darah sebelum perlakuan tersebut dapat disimpulkan bahwa rata-rata tekanan darah di Desa Bedahlawak Tembelang Jombang 150/90mmHg. Dengan ini membuktikan bahwa tekanan darah sangat rentan menyerang usia 60 tahun ke atas dan ini juga dipengaruhi oleh faktor ketidaktahuan akan pentingnya memeriksakan kesehatan dan mengontrol tekanan darahnya ke pelayanan kesehatan. Hipertensi menjadi penyebab utama stroke yang membawa kematian yang tinggi. Sebagai suatu proses degeneratif ditemukan kecendrungan peningkatan prevalensi hipertensi menurut peningkatan usia, yang sebagian besar responden berusia 60-70 tahun mayoritas penderita tidak menyadari diri sebagai penderita hipertensi. Karena itu mereka cendrung untuk menderita hipertensi yang lebih berat karena penderita tidak berupaya mengubah dan menghindari kebiasaan sehari-hari yang dapat meningkatkan tekanan darah. Berdasarkan analisa peneliti tekanan darah sesudah perlakuan yaitu pemberian jus buah naga merah dan melakukan pemeriksaan kesehatan secara teratur dan mengkonsumsi obat yang tepat serta dapat mengubah gaya hidup, pola makan dan menghindari kebiasaan sehari-hari yang dapat meningkatkan tekanan darah, sangat berpengaruh terhadap penurunan tekanan darah itu sendiri, yang mana setelah perlakuan tekanan darah responden mengalami menurunan rata-rata sistole 142,31. Hal ini juga dibuktikan dari hasil uji statistik t-test yang menyatakan bahwa ada pengaruh pemberian buah naga terhadap tekanan darah pada penderita hipertensi di Desa Bedahlawak Tembelang Jombang yang signifikan, hal ini sejalan dengan penelitian Komang, dkk (2014) bahwa buah naga juga mengandung antioksidan yang bermanfaat dalam menjaga elastisitas pembuluh darah, mampu memperbaiki sistem perdarahan darah.

Dari hasil penelitian tabel 5 didapatkan sistole rata-rata sebelum pemberian edukasi 152,31 dan setelah diberikan edukasi rata-rata sistole 155,38, dengan selisih mean sebesar 3,08 ini menunjukkan bahwa pengaruh kontrol sebesar $2,01 \%$, akan tetapi arahnya negatif. Dari uji statistik t-test paired didapatkan nilai $t_{\text {hitung }}$ sebesar -2,309 (sebelum dan sesudah kontrol) dengan nilai probabilitas sebesar 0,040 lebih kecil dari nilai standart signifikan $(\alpha=0,05)$, maka $\mathrm{H}_{1}$ diterima yang artinya ada pengaruh tindakan kelompok kontrol terhadap tekanan darah pada penderita hipertensi di Desa Bedahlawak Tembelang 
Jombang yang signifikan dengan arah pengaruh negatif.

Penatalaksanaan hipertensi dapat dilakukan dengan menggunakan obat-obatan ataupun dengan cara modifikasi gaya hidup. Untuk pemilihan serta penggunaan obatobatan hipertensi disarankan untuk berkonsultasi dengan dokter keluarga (Kementerian Kesehatan RI, 2014). Menurut Suiraoka (2012) faktor-faktor hipertensi ada yang dapat dikontrol dan tidak dapat dikontrol, yaitu faktor yang dapat dikontrol yang meliputi : kegemukan (obesitas), kurang olahraga, konsumsi garam berlebihan, merokok dan mengkonsumsi alkohol dan stres. Faktor yang tidak dapat dikontrol meliputi : keturunan (genetika), jenis kelamin dan umur.

Dari uraian di atas bahwa pada kelompok kontrol mengalami perubahan tekanan darah, akan tetapi perubahan tekanan darah arahnya negatif yang mana tekanan darah mengalami peningkatan atau tidak berubah sama sekali setelah diberikan edukasi tentang kebiasaan sehari-hari yang dapat meningkatkan tekanan darah kurang diperhatikan oleh responden. Selain itu peningkatan tekanan darah pada kelompok kontrol dikarenakan beberapa faktor, yaitu kurang aktivitas olahraga di lapangan ditemukan bahwa mayoritas responden tidak melakukan aktivitas olahraga, hal ini secara tidak langsung mengakibatnya penurunan kerja jantung, sehingga peredaran darah kurang maksimal yang mengakibatkan peningkatan tekanan darah, hal sesuai menurut Suiraoka (2012), orang yang kurang aktif melakukan olahraga pada umumnya cenderung mengalami kegemukan dan akan menaikkan tekanan darah. Dengan olahraga kita dapat meningkatkan kerja jantung, sehingga darah bisa dipompa dengan baik ke seluruh tubuh.

Terjadinya peningkatan tekanan darah pada kelompok kontrol, selain kurang memperhatikan edukasi yang diberikan oleh peneliti, yang mana mayoritas responden setiap harinya mengkonsumsi garam rata-rata $>1 / 4-1 / 2$ sendok teh (6 gram/hari). Mengkonsumsi garam dengan jumlah yang terlalu besar dapat menigkatkan volume plasma atau cairan tubuh dan tekanan darah, apa lagi mayoritas responden mengalami menderita hipertensi mengkonsumsi garam yang berlebih memicu peningkatan tekanan darah, hal ini sesuai menurut Suiraoka
(2012), garam merupakan hal yang sangat penting pada mekanisme timbulnya hipertensi. Pengaruh asupan garam terhadap hipertensi adalah melalui peningkatan volume plasma atau cairan tubuh dan tekanan darah. Kandungan garam natrium yang dikonsumsi berlebih menyebabkan konsentrasi natrium di dalam cairan ekstraseluler meningkat. Untuk menormalkannya kembali, cairan intraseluler harus ditarik keluar sehingga volume cairan ekstraseluler meningkat. Meningkatnya volume caira ekstraseluler tersebut menyebabkan meningkatnya volume darah, sehingga berdampak pada timbulnya hipertensi.

Dari hasil penelitian tabel

5menunjukkan nilai t sebesar 3.790 dengan nilai probabilitas sebesar 0,001 lebih kecil dari nilai standart signifikan $(\alpha=0,05)$, maka $\mathrm{H}_{1}$ diterima yang artinya ada perbedaan antara kelompok perlakuan dengan kontrol terhadap tekanan darah pada penderita hipertensi di Desa Bedahlawak Tembelang Jombang yang signifikan.

Tekanan darah dipengaruhi volume sekuncup dan total peripheral resistance. Apabila terjadi peningkatan salah satu dari variabel tersebut yang tidak terkompensasi maka dapat menyebabkan timbulnya hipertensi. Tubuh memiliki sistem yang berfungsi mencegah perubahan tekanan darah secara akut yang disebabkan oleh gangguan sirkulasi dan mempertahankan stabilitas tekanan darah dalam jangka panjang (Kaplan, 1998 dalam Nuraini, 2015). Oksidasi yang berlebihan terhadap asam nukleat, protein, lemak dan DNA sel dapat menginisiasi terjadinya penyakit degeneratif. Menurut Zainoldin (2012) dalam Wahdaningsih, dkk (2014), buah naga merah memiliki kandungan lycopene yang merupakan antioksidan alami dan dikenal untuk melawan kanker, penyakit jantung, dan merendahkan tekanan darah. Buah naga mengandung antioksidan yang bermanfaat dalam menjaga elastisitas pembuluh darah (Komang, dkk, 2014).

Dari uraian di atas dapat disimpulkan bahwa jus buah naga merah mampu mempengaruhi tekanan darah pada penderita hipertensi, hal ini dilihat dari uji statistik yang menyatakan bahwa kelompok yang diberikan perlakuan, yaitu jus buah naga merah memiliki perbedaan yang signifikan dengan kelompok kontrol yang tidak diberi jus buah naga merah, hal ini sesuai dengan pendapat Nell Solomon (2016) untuk Hopkins Hospital, 
USA menyatakan bahwa minum jus buah naga dua kali sehari sebanyak satu gelas akan mendapatkan khasiat, yaitu untuk kesembuhan penderita hipertensi menggunakan buah naga.

\section{SIMPULAN DAN SARAN}

\section{Kesimpulan}

Berdasarkan hasil penelitian dan pembahasan yang telah diuraikan pada bab sebelumnya, dapat disimpulkan sebagai berikut : 1) Hampir setengah responden tekanan darah sebelum perlakuan kategori hipertensi derajat II, 2) Hampir setengah responden tekanan darah sesudah perlakuan kategori prehipertensi, 3) Ada pengaruh pemberian buah naga terhadap tekanan darah pada penderita hipertensi di Desa Bedahlawak Tembelang Jombang yang signifikan.

\section{Saran}

Bagi Tenaga Kesehatan

Hendaknya tenaga kesehatan melakukan langkah-langkah untuk melakukan penekanan terjadinya hipertensi, yaitu dengan memberikan penyuluhan lebih intensif tentang kebiasaan sehari-hari yang dapat meningkatkan tekanan darah seperti tidak mengkonsumsi garam tidak lebih dari $1 / 4-1 / 2$ sendok teh (6 gram/hari), tidak minum kopi dan alkohol, melakukan olahraga dan mengkonsumsi buah naga merah, sehingga peningkatan tekanan darah dapat dicegah dan ditangani secara optimal.

\section{Bagi Masyarakat}

Hendaknya masyarakat meningkatkan informasi khusus penderita hipertensi tentang pentingnya buah naga merah dalam menurunkan tekanan darah, sehingga dapat semakin dikenal luas dan dikembangkan pemanfaatannya sebagai alternatif pengobatan penunjang pada penderita hipertensi

\section{Bagi Peneliti Selanjutnya}

Perlu adanya penelitian lebih lanjut mengenai kemampuan antioksidan pada buah naga merah terfermentasi dalam mencegah terjadinya oksidasi oleh radikal bebas pada hipertensi, serta sebagai referensi dalam penelitian yang berkaitan dengan tekanan darah pada penderita hipertensi.

\section{KEPUSTAKAAN}

Akmal. 2010. Ensiklopedi Kesehatan Untuk Umum. Jakarta : Ar-Ruzz Media.

Adib. 2011. Pengetahuan Praktis Ragam Penyakit Mematikan Yang Paling Sering Menyerang Kita. Yogyakarta : Buku Biru.

Azzahra. 2014. Buah Naga. Available online: (https://azzahrablog.wordpress.com/ tag/buah-naga/diakses, 06-12-2016)

Amelia. 2015. Uji Aktivitas Antibakteri Fraksi n-heksan Kulit Buah Naga Merah (Hylocereus polyrhizus Britton \& Rose) Terhadap Bakteri Staphylococcus aureus ATCC 25923. Traditional Medicine Journal, 19(2).

Barbara. 2003. Asisten Keperawatan-Suatu Pendekatan Keperawatan Ed. 6. Jakarta : EGC.

Dwipayanti. 2011. Efektifitas Buah Belimbing Terhadap Penurunan Tekanan Darah Pada Penderita Hipertensi di Sumolepen Kelurahan Balongsari Kota Mojokerto. Jurnal Keperawatan, Vol. 01, No. 01. Desember 2011

Fridalni. 2013. Pengaruh Pemberian Jus Semangka ( Cilitrus Vulgaris Schrad) Terhadap Penurunan Tekanan Darah Lansia Dengan Riwayat Hipertensi di Kota Padang. Jurnal Keperawatan, Vol. 01, No. 01, September 2013.

Hidayat. 2009. Metode Penelitian Keperawatan dan Teknik Analisis Data. Jakarta : Salemba Medika.

Hidayat. 2010. Metode Penelitian Keperawatan dan Teknik Analisis Data. Jakarta : Salemba Medika.

Harjana. 2013. Kandungan Manfaat dan Khasiat Buah Naga untuk Kesehatan. Available online : (http://manfaatnyasehat. blogspot.co.id/diakses, 03-12-2016)

Kharisna. 2012. Efektifitas Konsumsi Jus Mentimun Terhadap Penurunan Tekanan Darah Pada Pasien Hipertensi. Jurnal Ners Indonesia, Vol. 2, No. 2, Maret 2012.

Komang, dkk. 2014. Jus Buah Naga Merah Menurunkan kadar Glukosa Darah Penderita DM tipe 2. Jurnal Skala Husada Vul. II No.1.

Kementerian Kesehatan RI. 2014. Hipertensi. Jakarta : Pusat Data dan Informasi Kementerian Kesehatan RI. 
Krisnadi. 2015. Kelor Super Nutrisi. Blora : Marindo.

Lizel. 2013. Pengaruh Terapi Diet Pisang Ambon (musa paradisiaca var. Sapientum Linn) Terhadap Penurunan Tekanan Darah Pada Klien Hipertensi di Kota Bitung. ejournal keperawatan (e-Kp) Volume 1. Nomor. Agustus 2013.

Mega. 2016. Teknik Budidaya Buah Naga di Bukik Galeh, Sarilamak. Jurnal Nasional Ecopedon Vol. 3 No 1.

Notoatmodjo. 2010. Metodologi Penelitian Kesehatan. Jakarta : Rineka Cipta.

Nursalam. 2011. Konsep dan Penerapan Metodologi Penelitian Ilmu Keperawatan. Jakarta : Salemba Medika.

Nuraini. 2015. Risk Factors of Hypertension. Atikel. Vol. 4, No. 5.

Putri. 2015. Aktivitas Antioksidan Antosianin Dalam Ekstrak Etanol Kulit Buah Naga Super Merah (Hylocereus costaricensis) dan Analisis Kadar Totalnya. Jurnal Kimia, Vol. 9, No. 2, Juli 2015.

Riduwan. 2010. Metode dan Teknik Menyusui Tesis. Bandung : Alfabeta.

Renasari. 2010. Budidaya Tanaman Buah Naga Super Red di Wana Bekti Handayani. Tugas Akhir. Fakultas Pertanian Universitas Sebelas Maret Surakarta.

Suiraoka. 2012. Penyakit Degeneratif. Yogyakarta : Nuha Medika.

Sayuti dan Yenrina. 2015. Antioksidan Alami dan Sintetik. Padang : Andalas University Press.

Solomon. 2016. Cara Membuat Ramuan Hipertensi Dari Buah Naga Merupakan Salah Satu Cara Termudah Mengontrol Tekanan Darah Secara Alami. Available online : (http://indonesiasehat.net/diakses, 22-11-2016).

Solehudin. 2014. Manfaat Buah Naga Merah Bagi Kesehatan. Available online : (http://kesehatanbadaninfo.blogspot.co.i d/2014/09/manfaat-buah-naga-merahbagi-kesehatan.htmldiakses, 01-122016).

Tohari. 2016. Gambaran Keteraturan Mengontrol Tekanan Darah Pada Pasien Hipertensi di Puskesmas Kedurus Surabaya. Jurnal Ilmiah
Kesehatan, Vol. 9, No. 1, Februari 2016, hal 49-51.

Umayah. 2007. Uji Aktivitas Antioksidan Ekstrak Buah Naga (Hylocereus undatus (Haw.) Britt. \& Rose) (Antioxidant Activity Assay of Dragon Fruit Extract (Hylocereus undatus (Haw.) Britt. \& Rose). Jurnal Ilmu Dasar, Vol. 8 No. 1.

Waji dan Sugrani. 2009. Flavonoid (Quercetin). Makalah. Program S2 Kimia. Universitas Hasanuddin.

Wahdaningsih, dkk. 2014. Antibakteri Fraksi n-Heksana Kulit Hylocereus polyrhizus Terhadap Staphylococcus epidermidis dan Propionibacterium acnes. Artikel. Pharm Sci Res ISSN 2407-2354.

Yanti. 2015. Daya Terima dan Kadar Vitamin C Sari Buah Kulit Buah Naga (Hylocereus Polyrhizus) dengan Proses Pengolahan yang Berbeda. Jurnal Skala Kesehatan Volume 6 No. 1 Tahun 2015. 